\title{
Colorectal Cancer pT1 TNM Finding v6 and v7
}

National Cancer Institute

\section{Source}

National Cancer Institute. Colorectal Cancer pT1 TNM Finding v6 and v7. NCI Thesaurus. Code C60844.

Colorectal cancer with invasion into the submucosa. (from AJCC 6th and 7th Eds.) 